This is a self-archived version of an original article. This version may differ from the original in pagination and typographic details.

Author(s): Pitkänen-Huhta, Anne

Title: Young People's Emerging Multilingual Practices : Learning Language or Literacy, or Both?

Year: 2019

Version: Accepted version (Final draft)

Copyright: @ 2019 Springer

Rights: In Copyright

Rights url: http://rightsstatements.org/page//nC/1.0/?language=en

Please cite the original version:

Pitkänen-Huhta, A. (2019). Young People's Emerging Multilingual Practices : Learning Language or Literacy, or Both?. In S. Bagga-Gupta, A. Golden, L. Holm, H. P. Laursen, \& A. Pitkänen-Huhta (Eds.), Reconceptualizing Connections between Language, Literacy and Learning (pp. 35-54). Springer. Educational Linguistics, 39. https://doi.org/10.1007/978-3-030-26994-4_3 


\title{
Young People's Emerging Multilingual Practices: Learning Language or Literacy, or Both?
}

\author{
Anne Pitkänen-Huhta ${ }^{1}$
}

\subsection{Introduction}

Research on language learning (or development) and research on literacy are usually seen as two separate strands of enquiry. Researchers of language learning very often work under the label SLA, second language acquisition. Their focus might be on learners, on learning (processes or outcomes), or on teachers; they focus on language - as oral or written, received or produced. Most often the focus is on languages other than the first/native language, traditionally labelled as the second or foreign language. Researchers of literacy, however, focus on reading or writing; on the reception or production of written texts. Their focus is very often on the first language or the second language and rarely, if ever, on foreign languages. The labels of first, second and foreign language are, however, becoming inaccurate and inadequate in describing most of our language use and learning today, especially in multilingual contexts, and so researchers are beginning to question the relevance of these terms (see e.g. Lo Bianco 2014). At the same time, learners and learning contexts are becoming increasingly varied, and making a distinction between the concepts of language and literacy is becoming more difficult - and perhaps unnecessary. It is indeed increasingly common to see researchers using language and literacy together, as one entity, in research questions, article titles, and argumentation (I have done this myself). Connecting these two concepts is, however, done as a default, without any explication as to the nature of the connection.

Keeping these concepts separate is at least partly due to the epistemological questions of what language and literacy are. Firstly, language can be conceptualized as a system and as structures which take spoken or written form, and accordingly, we may understand

\footnotetext{
${ }^{1}$ Department of Language and Communication Studies University of Jyväskylä, Finland anne.pitkanen-huhta@jyu.fi
} 
literacy as the skill of reading and writing, i.e. of understanding and producing language in its written form. Therefore, when using the two terms together the researcher might be indicating that they want to combine spoken language and text (written language), or language (be it whether spoken or written) and the act of reading and/or writing. The distinction between the concepts seems obvious when taking this kind of approach to language and literacy. But if we look at these terms and related actions from another epistemological vantage point, that is, from a social, socio-cultural, and ecological viewpoint, the distinction needs to be re-examined. If we understand language as a resource with its roots in history and culture, we also see literacy as a social practice, as something people do with texts. With this take on language and literacy, there might be little sense in keeping the two concepts completely separate.

In this chapter, I hope to bring into dialogue research on literacy practices and research on language development and use in two different contexts of multilingual language use. My goal is to examine language use and language learning in relation to literacy practices through two studies. Taking literacy practices as the focus and examining how language use and language learning are connected to these practices will enrich our understanding of how language is intertwined in social practice, and how literacy may precede, bypass, or restrict language use.

\subsection{Language as a System and as a Resource}

Our conceptualization of language affects how we see language use and language learning. Language has for long been understood as a system that can be codified, standardized, preserved, and protected. Languages have been seen to exist only in this codified standard form, and the ability to use the standard form has been the goal of education (García 2009). Until quite recently, language education was also based on this idealized standard form of language, and mostly in written form, to the extent that it can be said that there has been a written language bias in linguistics (Linell 2005). However, recently there has been criticism, on the one hand, of the view of language as a system in SLA research and practice (e.g. Block 2003, Firth and Wagner 1997, 2007) and, on the other, of the monolingual bias in SLA (e.g. May 2011). In his criticism, Block (2003) points out that at first, language was seen as morphology and syntax, then slowly phonology and lexis were added, and then 
pragmatics, but nevertheless the goal of language learning continued to be a system with a codified structure based on the native speaker model. This is particularly evident in connection to foreign languages, which have typically been learned in institutions only and the goal of learning has been something ideal outside the actual learning environment. Its appropriate use has then been the basis of foreign language education, in which language has been objectified into structures and wordlists and placed within textbooks (PitkänenHuhta 2003, Nikula 2002).

Block (2003) describes aptly how language in SLA has developed from linguistic competence to communicative competence, but the focus has still been on communication in one whole language, such as English or German. This view of language as a system has been prevalent both in research and practice for decades. As Canagajarah (2013, p. 12) points out, "the notion of bounded languages, with neatly patterned grammatical structures of their own, has been an asset for product-oriented teaching”. In recent years we have, however, seen a move towards approaches that take into account the complexity of language use and the contexts in which language is used. One example of this move is the complexity theory (CT) and its application in SLA. Larsen-Freeman (2013, p. 369) says that "from the beginning of my acquaintance with CT ... It challenged my concept of language as a static rule-governed system”. Similar critique towards mainstream SLA research has been presented in relation to multilingualism. May (2011), for example, argues for an additive bilingual approach to SLA and TESOL and shows that there has been critique since the early 1990s. There is, then, ample scientific evidence that language use is extremely diverse and heterogeneous. Nevertheless, as the Douglas Fir group (2016, p. 35) say, despite all this evidence, "the bulk of research in SLA and many areas of applied linguistics continue to rely on the monolingual native speaker's idealized competence as a benchmark for defining and evaluating L2 learning".

At the same time, research on (multilingual) language use has shown that language is best seen as a resource, as something that is used to get something done, and then the systematic nature of language is not in a central role (e.g. Kramsch 2014, Blommaert 2010, Makoni and Pennycook 2007). Pennycook (2010, Otsuji and Pennycook 2010) characterizes language as a local practice, which means that we are not, in fact, talking about language per se but about how people engage in local practices and how they make use of the various resources available to them to accomplish their purposes. Similarly, Canagarajah (2007, p. 236) says that "what speakers need are ways of negotiating difference rather than codes that 
are shared with others". What this means in language education is that we should not start with the language but with what people want to accomplish with the language. Thus, knowing languages "refers not so much to the mastery of a grammar or sociolinguistic system, as to the strategic capacity to use diverse semiotic items across integrated media and modalities" (Pennycook 2010, p. 129).

However, in language education we cannot escape the fact that learning the system and being able to use the standard are necessary skills. As Otsuji and Pennycook (2010) point out, we should not see fixity and fluidity as opposites or as dichotomous but as existing at the same time and constituting each other. In a recent article, Pennycook and Otsuji (2016, p. 270) revisit their discussion on fixity and fluidity and conclude that "language practices and identity are formed in a constant push and pull between fixity and fluidity". Thus, language can be seen at the same time as a system and a resource; as a language with fixed and codified boundaries and as a localized resource used to reach individualized needs and goals.

\subsection{Literacy Practices and Language}

For a few decades now there has been a clear division between two lines of research on literacy: literacy as a skill to be learnt and taught, and literacy as social practice (e.g. Street 1984, Barton and Hamilton 1998, Baynham and Prinsloo 2009). The epistemological differences between these two approaches stem from their different research orientations. The first has its roots in psychologically and structurally oriented research on reading and writing, and the second in sociolinguistic and ethnographic research on practices and social action. The differences are also related to the distinctions in how we conceptualize language described above. When language is understood as a system and structures, literacy can also be seen as one form - the written form - of language and as a skill to be learnt. What is more, when the starting point is a skills-based approach to literacy, literacy most often seems to equal reading. In this view, language precedes literacy in the sense that one first needs to learn/acquire the spoken language and only then is it possible to learn the written language, i.e. literacy. This is already the case with young children learning to read and write in their first language, but it is especially the case when second and foreign languages are concerned. It is assumed that one first needs to learn the basic structures of the new language before one 
can read or write anything beyond a simple sentence or two. In SLA research, the term threshold has been used to point to a certain level of language proficiency before, for example, one is able to read. This view of language learning in stages has also effectively kept language and literacy separate. One has to have language before literacy.

On the other hand, when we see language as a resource and language use as practices, we also conceptualize literacy as a practice: it is something that people do with texts (Barton and Hamilton 1998, Barton et al. 2007), and the focus shifts from the outcome or product to the social action around the use of texts. In research on literacy practices, the focus of research has also been strongly on the vernacular: on people's everyday text-related activities, which can be very rich and nuanced, but which are mostly ignored in education. In addition, when we are concerned with practices we are essentially dealing with more than just activities: we need to consider the values, attitudes and emotions that are related to literacy. To understand literacy practices and the role of language in them, we need to examine, interpret and understand people's perceptions and understandings of the practices they engage in and the values they place on them. In education, this view of literacy entails a critical (e.g. Shor 1999) and emancipatory take on both literacy and education (Freire and Macedo 1987). Paulo Freire's (e.g. 1970) seminal idea of reading the word and reading the world aptly points to the fact that the mere skill of decoding - even though an essential basic skill - is not enough for full participation in society. Education needs to provide learners with tools to critically engage with language and literacy to gain access to societal action.

Seeing language as a resource and shifting the focus away from the idealized native speaker of any one particular language also means that our resources can be emerging, partial, and multimodal, and can cross borders between languages. We do not need to possess full knowledge of a language, but we can perform social action with bits and pieces of languages (Blommaert 2008). Also, we do not rely only on linguistic resources when aiming at getting something done; instead, we have the full potential of all semiotic resources at our disposal. This is truer now than ever before, with technology fast changing our ways of communicating. Our idea of "text" is therefore also wide and varying.

Hornberger $(1989,2003,2007)$ was one of the first researchers to problematize the connection between literacy and language in bi- (or multi)lingual contexts. Her early work in the late 1980s proposed a framework for understanding biliteracy which she calls the continua of biliteracy, which draws on the view of multilingualism as a resource and on ecological views of language learning. She (Hornberger 2003, p. XV) states that "the very 
notion of bi- (or multi-)literacy assumes that one language and literacy is developing in relation to one or more other languages and literacies (language evolution)". There is also other research evidence that language and literacy can develop at the same time. Lau (2012), for example, examined how critical literacy (CL) was connected to language learning with students with limited skills in English. Lau (2012) found that in addition to gaining linguistic skills, the students also gained confidence in expressing their opinions. She (Lau 2012, p. 329) points out that "the assumption that the development of CL skills can be postponed until students have achieved higher levels of language proficiency reflects a belief that literacy is a purely psychological or developmental phenomenon". In her study, critical literacy and language developed side by side.

To illustrate the connection between language and literacy in this chapter, I will take a new look at two ethnographic data sets that have been collected in two different research projects: one looking at the everyday uses of English by young Finnish people, and the other examining the Sámi language context in Northern Finland. I will present the projects in Section 4 and then discuss the data from each project in Section 5.

\subsection{Data from Two Research Projects}

This chapter draws on data from two research projects. The data were not originally collected for the purposes of this chapter and the principal focus of the projects was not on language, literacy, and learning. However, I focus here on the perspective of literacy practices in the projects and see how connections between the concepts of language, literacy, and learning emerge from the data.

The first project was a discourse-ethnographic project ${ }^{2}$ that examined how Finnish young people use English in their everyday lives and how they make sense of their practices (Nikula and Pitkänen-Huhta 2008, Pitkänen-Huhta and Nikula 2013). The project was run by Tarja Nikula and myself. The participants were three groups of 14-16-year-old Finns (three boys, four girls and three girls). All the participants had started studying English at school in year 3, so they had studied English for 7-8 years at the time of data collection.

${ }^{2}$ Anne Pitkänen-Huhta and Tarja Nikula, part of the Centre of Excellence funding (Academy of Finland, 2006-2011) 
From Year 7 onwards they had all also had Swedish as a compulsory subject, so they had studied it for 3-4 years. As for other languages, apart from English and Swedish, only one boy had chosen to study German for 6 years, and one of the girls studied Japanese in her free time. All the participants were from Finnish-speaking families. Following the principles of ethnography, we maintained contact with the young people for a lengthy period of time: 16 months with one group of boys and girls (the data collection with these groups ran simultaneously) and 5 months with one group of girls (the data collection took place later). We did not follow them in their everyday activities and observe their practices on site, but we followed their lives through different indirect means and met them regularly for discussion and other activities. The means of gaining access into their lives included group discussions with girls and boys separately at both the beginning and end of the project, group discussions based on photographs the participants took of their contacts with English, discussions on their literacy diaries concerning encounters with texts in English and Finnish, the participants' discussions in pairs about specific contexts where they had used English (conducted and recorded without the researchers' presence), and individual discussions based on a visual task depicting the participants' relationship with both English and Finnish. The discussions followed a semi-structured format in that the researchers had an outline for the discussion themes, but any other themes were allowed to emerge during the discussion. The group discussions were conducted in three groups (one for the boys, two for the girls). This was because the boys and girls in these groups knew each other rather well and were also friends outside school. This was important as the focus was on everyday activities. In addition, the researchers wanted to create a friendly and supportive atmosphere in the discussions. The take on data collection was therefore participatory, as the basis of most of the discussions was data first gathered or created by the participants themselves.

For the purposes of this chapter, I will focus here on the participants' literacy diaries and the discussions on them. Keeping a literacy diary meant that the participants monitored their daily contacts with texts, whether in Finnish, English, or any other language, and recorded them in little notebooks. They were instructed to note down all the texts they had seen, read or written during the day outside school, for seven days. The idea was to get an insight into their everyday literacy practices and into the role of English in these practices. They returned the diaries to the researcher and after the researcher had had time to read the diaries through, group discussions were organized, again with boys and girls separately. This part of the research project was carried out by myself only. 
The second data set comes from a large ethnographic research project in Finnish Sámiland run by Sari Pietikäinen (Northern Multilingualism: Discourses, Practices and Experiences of Linguistic Diversity in North Calotte, 2008-2011). The project focused on a theoretical and empirical investigation of multilingualism in the transnational North Calotte and it investigated several locations with particular reference to media, tourism, families, schools and landscapes (e.g. Pietikäinen 2015). I will focus here on the data collected in schools in 2009-2010. I was not a researcher on site, but I have visited the site and met the teachers, and I have analysed the school data together with Sari Pietikäinen (see also Pietikäinen and Pitkänen-Huhta 2013, 2014, Pitkänen-Huhta and Pietikäinen 2014).

The classrooms in focus here are integrated classrooms of Northern Sámi and Inari Sámi, from preschool to year 6. The languages used as the media of instruction are Finnish, Northern Sámi, and Inari Sámi. The children were between 6-12 years old at the time of data collection. They are speakers of Finnish and Northern Sámi and/or Inari Sámi and their linguistic repertoires also include other languages, including other family languages, languages learnt at school (mostly English), and tourists' languages.

I will focus here on a specific part of the project in which a participatory approach (Freire 1970, Auerbach 1995) was used in the data collection (Pitkänen-Huhta and Pietikäinen 2014). In this part of the project, the children engaged in various verbal and visual activities, the goal of which was creating a children's picture book (Figure 2.1).

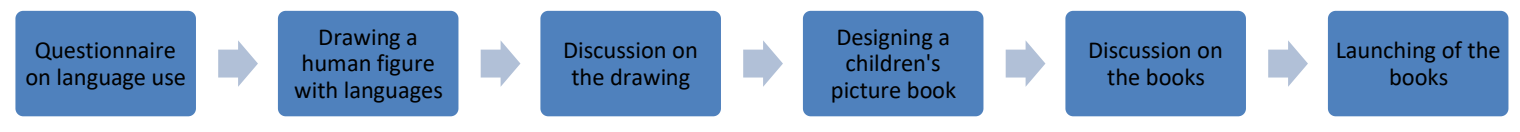

Fig. 2.1 Activities in the participatory research process

The data used in this chapter include the questionnaire on language use, the multilingual children's picture book, and the group discussions with the children before and after making the book. ${ }^{3}$ The children made a multilingual and multimodal (drawings were included) children's picture book, which was officially printed, launched and circulated. Around the

\footnotetext{
${ }^{3}$ For discussion on the task as a pedagogical task see Pitkänen-Huhta and Pietikäinen (2014) and on the drawing task see Pietikäinen and Pitkänen-Huhta (2013, 2014).
} 
literacy task there was talk about languages and multilingualism in the children's lives with the aim of raising their language awareness and exploring their own practices.

What is worth noting here is that the practice took place in a minority language context, where written text has a specific role. It is a powerful means of language maintenance and authority. As Jaffe (2003, p. 203) points out, "literacy practices are also indices of the complexities of linguistic and cultural identification for people whose lives and definitions of self are shaped by both minority and dominant cultures".

\subsection{Connecting Literacy Practices and Language Learning/Use}

\subsubsection{Data Set 1: Young People's Literacy Practices}

With the data examples below I will argue that when young people engage in everyday literacy practices in languages that are not their first languages and in which they have varying competences, the concepts of language and language learning get new meanings. The following data extracts are from discussions that were conducted after the young people had kept a literacy diary for a week. The discussions took place in groups, three boys, four girls, and three girls. Examples come from all three discussions.

The first three examples show how literacy practice gets priority over language competence, i.e. the primary goal is to get something done. In the first data extract, Erik talks about his practice of reading about his favourite sport, football (or soccer) in newspapers and sports magazines:

\section{Extract $^{4}$ 2.1: Football}

Interviewer luetsä pääasiassa suomalaiset suomalaiselta sivulta sit do you mainly read Finnish stuff from Finnish pages then

Erik joo suomenkielisiltä sivuilta mut sitte oli just tuo yks (0.7) jalkapallojoukkueen sivu joka on englantilainen siellä oli ne englantilaiset sivut ni ni siellä sitten englannilla piti pärjätä

\footnotetext{
${ }^{4}$ The interviews were conducted in Finnish. The extracts have been translated by the author. The translations are rough and punctuation is added to ease understanding. Pauses are marked in brackets in seconds (numbers), if they were long and if they are relevant in the interpretation of the extract. Some words that appeared in an earlier context but that are necessary to understand the extract have been added in square brackets.
} 
yeah from Finnish pages but then there was this one (0.7) page on a football team which is in English, there were those English pages, so then you had to cope in English

Interviewer joo

Yeah

(0.8)

Erik ja ihan hyvin pärjäski ei siellä siellä sinänsä ollu mitään niin semmosta monimutkasta että and I did quite well, there wasn't anything very complicated there

Interviewer joo

yeah

Erik termit on tuttuja sieltä sitte englannin puolelta the terms were familiar then in English

The interviewer (the present writer) asks whether Erik reads mainly Finnish magazines and Erik responds yes, he reads Finnish stories but there is one English sports magazine in his list. He notes that he had to manage in English and, after quite a long pause, he points out that he did manage well, and that the English terms were familiar to him. Erik - like the others - has studied English at school and, given the prominent position of English in young people's everyday lives (see Leppänen et al. 2011), it is quite natural that Erik can cope in English. What is worth noting here is that there are long pauses before Erik comments on language use. The fact that Erik clearly has to think how to do this may indicate that language as such was not an issue here.

Through their literacy practices, these young people also encounter languages that they were much less familiar with than English. All of these young people also read magazines or web pages in languages that they know less well or not at all. The following two short extracts come from Eeva and Siiri:

\section{Extract 2.2: Magazines}

Eeva mut sit mulla on ranskalaisia ja saksalaisia [lehtiä], sellasia niitä mää en kyllä kauheesti tajua mutta ne on kans ihan hyviä then I have French and German [magazines], I don't get much from them, it's true, but they're quite good as well

Extract 2.3: Webpages 
Siiri mä pääsin nettiin elikkä siellä olin aika kauan esimerkiks kävin tollasessa asos piste com se on niin ku englanninkielinen siellä on kaikkea asusteita ja kaikkee hienoo vaatteita sitte mää eksyin jollekin ruotsinkieliselle blogeille ja muotiblogeille ja kaikille tämmösille no emmää kyllä oikein tajunnu niitä mutta olihan se silti ihan kivaa ja tällei lukee

I got on the net, so I spent a lot of time, I visited for example [the page] asos dot com, it's kind of, it's in English, there are all kinds of accessories and such like, fancy clothes, then I got lost in some sort of Swedish blogs and fashion blogs and so on, well I didn't get much out of them but it was still kind of nice and so to read

In Extract 2.2, Eeva talks about her reading French and German fashion magazines, saying that she does not understand much but they are good anyway. In Extract 4.3, Siiri tells about her practice of surfing on the internet and how she happened upon some Swedish fashion blogs, which again she did not understand much of. Here the practice is more important than the language involved; one copes in a less familiar language if one must get the social action done. It is important here that the young people's practices concern their hobbies or other personal interests, and therefore there is clearly investment (see e.g. Norton 2000) in getting something out of these magazines even though the language is not very familiar. What is perhaps more important than the language of the text is being part of the (imagined) community (Anderson 1983, Pitkänen-Huhta and Nikula 2013) around the hobby through these magazines. One could contrast this with a situation in which these young people were given a task at school for which they had to read a text in German: I am quite convinced that they would say they could not do it because they do not know any German.

What is the language then that these young people use in their literacy practices? Eeva explains quite nicely how she sees the English she uses when writing on discussion forums:

\section{Extract 2.4: Not real English}

Interviewer huomaattekste kun te kirjottelette siellä että tuleeks siellä sitä englantia kirjoteltua onks siellä onks teillä jotain vakiojuttuja tai

do you pay attention, when you write there, do you write in English, is there some regular stuff there or

Eeva no ei ei ehkä hirveesti sellasta ihan varsinaista englantia no tietysti niitten kans kenen kaa puhuu englantia mutta nii sellasia niinku englannista niinku tulevia sanoja vähän sellasta niinku 
well no, maybe not so much kind of real English, well of course with those who you always speak English with, but it's more like words that come from English, kind of like, you know

When the interviewer asks whether the girls also write in English, Eeva replies that it is not really proper English, except when you use English all the time with somebody. But the language they use is words based on English. This again is an indication of both the fixity and fluidity of language: sometimes the participants talk about whole languages and sometimes they describe their language use as bits and pieces of language, depending on the context and the needs of the people involved (cf. Pennycook and Otsuji 2016).

The data also shows that language learning is connected to literacy practices. In the following extract (Extract 2.5), Taavi and Erik talk about song lyrics. Checking lyrics online was a practice that all these young people engaged in.

\section{Extract 2.5: Lyrics}

Interviewer mites teillä teillä tais kummallakin olla näitä näitä tota noin niin tämmösiä kappaleitten sanotuksia ja tämmösiä niin tota oliko käy- käyttekste kumpikin sellasia hakemassa kattomassa luette niitä how about these lyrics, you both had these these, well like song lyrics and the like, so was it-do you both search for these and read them

Taavi kyl mää ainaki yeah I at least do

Erik kyl mää ainaki käyn just joku uus kappale minkä on just kuullu ni sieltä saattaa ihan mielenkiinnosta vaan kattoo että kattoo et miten sanat menee ja hoilaako ite ihan väärin tai jotain

yeah I do at least when there's a new song that I've just heard, so I can just out of curiosity go and go and check what the lyrics are and whether I'm singing it completely wrong or something

Taavi just joku sana jota se lausuu sen jotenkin ouosti ja sit ei ite tajua ni käy varmistaa sitte että mitä siel on

if there's a word that someone pronounces in a weird way and then you don't get it, so you go and check what it really is

The literacy diaries of both Taavi and Erik included lyrics, and the interviewer asks about these. Erik says that he looks for the lyrics of new songs he has heard to check what exactly the lyrics say, so that he can avoid singing it completely wrong. Taavi adds that he 
checks words that he does not catch because of the way they are pronounced in the song. This practice involves an element of language learning that is very close to the traditional dictionary work learnt at school but is now connected to everyday practices and personal interests. Even though the focus of discussion was everyday literacy practices outside the classroom, school features quite prominently in young people's lives. For one thing, they are learners of languages at school and there is a leaking of practices between different domains, to use Barton and Hamilton's (1998) formulation. Therefore, literacy practices and language learning - and the concepts of literacy and language - seem to be connected.

What does this data on young people's literacy practices tell us about the relationship between language, literacy, and learning? To summarize the main observation in just a few words, one could say that the practice (or the social action) comes first and the language follows, and language learning takes place as a side product. When the young people talk about their literacy practices, it becomes evident that these practices are related to their hobbies and personal interests. In their practices, their goals of getting information or being part of a community around that particular interest are intertwined with language: they use the resource that is relevant. If it is a foreign football team, they turn to language other than Finnish. What is remarkable here is that even languages in which they have very limited knowledge (to use the conventional terminology) play a role in these practices and there seems to be no language barrier. Knowledge of the key terminology related to one's favourite hobbies (e.g. snowboarding) gives access to languages of which one has very limited, if any, knowledge. It may also be that images, i.e., all semiotic resources, are used when trying to get access to international communities around their personal interests. As the hobbies in question were sports and fashion, photography plays an important role in magazines and web sites. So it seems that language is embedded in the practices and that literacy practices are intertwined in language use and language learning. When we look at language through the lens of literacy practices, language no longer seems to be a skill, a proficiency level or a product but a resource that is used to reach a goal.

\subsubsection{Data Set 2: Multilingual Sámi Children Conceptualizing Language}

With this data set, I will argue that understanding and making use of one's varied and multilayered language repertoire is highly contextual and that the nature and purpose of the literacy practice may set boundaries to the use of this repertoire. In contrast to the previous 
example, the children in the following example are engaging in a more formal and public literacy practice which is being carried out in the school context. In the following, I will present one child as a case example.

Oona was 8 years old at the time of data collection and she was in Inari Sámi medium education at school. To begin the activities related to raising multilingual awareness and the literacy practice of designing the picture book, all the children filled in a questionnaire (Figure 2.2), which included questions on their language use and feelings and metaphors related to the use of different languages. In this chapter, only the questions related to language use are analysed, and for the sake of clarity, these questions are presented in English after the Figure.

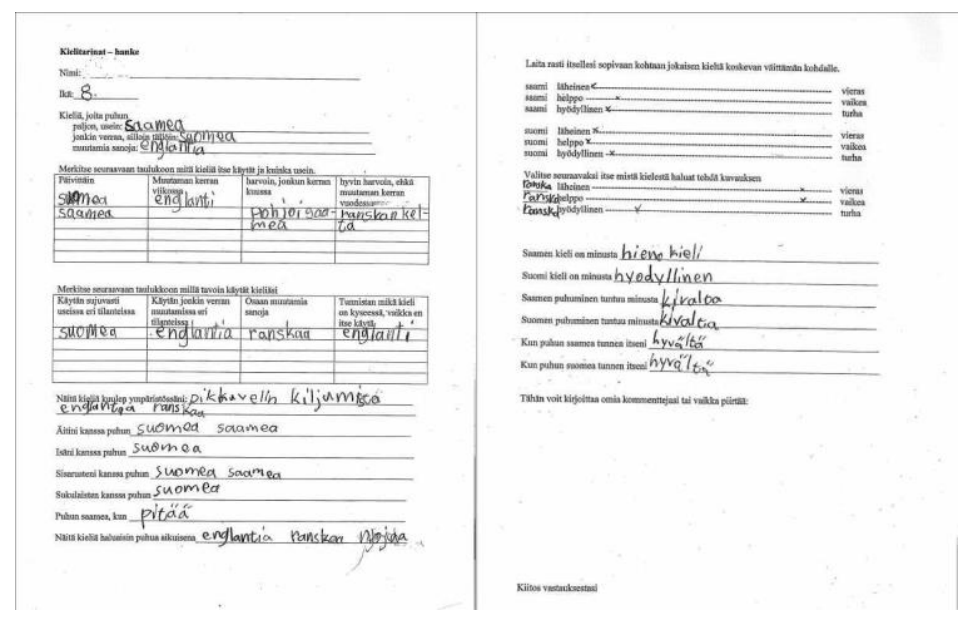

Fig. 2.2 Oona's questionnaire form

Questions on language use (the first page of the questionnaire):

- Languages that I speak

- a lot, often

- a little, sometimes

- a few words

- Mark in the table what languages you use and how often (daily, a few times a week, seldom/a few times a month, very seldom/maybe a few times a year)

- Mark in the table how you use your languages

- I use it fluently in several different situations

- I use it a little in different situations

- I know a few words 
In her questionnaire, Oona lists several languages that in one way or another belong in her repertoire (representation by the author of Oona's repertoire in Figure 2.3). The languages she lists are Inari Sámi, Northern Sámi, Finnish, Norwegian, English, French, and the Screaming of my little brother. What is interesting in this list is that the screaming of my little brother is a language in Oona's repertoire and tells in a powerful way how a bottom-up conceptualization of language may differ quite considerably from our conventional way of categorizing languages. For Oona, this screaming is obviously a means of conveying meaning, and maybe often heard at home. Another interesting point is that Oona has not started to study any foreign languages at school and yet she readily lists several languages in her repertoire. Many of these languages may be present in Oona's life through tourism in the North. On the basis of the questionnaire, one could say that Oona has a very wide language repertoire.

The questionnaire also asked in different ways how the different languages were used, how often, and with whom. It is interesting that the same language might be placed in different boxes in the questionnaire. Oona put English, for example, in three different boxes: I use it a few times a week; I use it a little in different situations; I recognize the language even though I don't use it myself. This may say something about the child's view of language use: it varies depending on the situation and the use may contain different elements, from seeing to actively using.

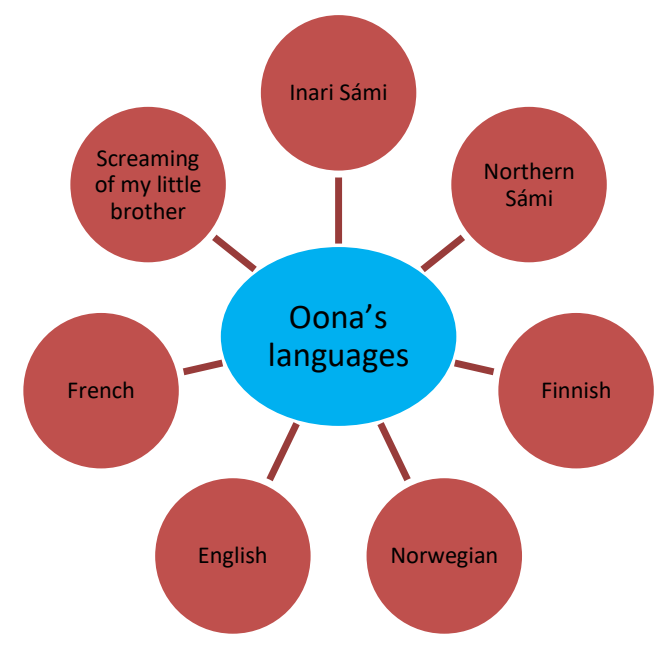

Fig. 2.3 Author's representation of Oona's language repertoire 
Oona described the use of the languages she mentioned in the following way:

- Inari Sámi: uses it a lot; uses it with mother, siblings, relatives

- Northern Sámi: hears in her environment

- Finnish: uses it a lot; uses it with father, mother, siblings, relatives

- Norwegian: would like to use it as an adult

- English: knows a few words; would like to use it as an adult

- French: knows a few words; would like to use it as an adult

- Screaming of my little brother: hears it in her environment

The use of languages reveals an interesting network of people and languages in Oona's environment. Inari Sámi and Finnish are used a lot and with all the people near to Oona. Some languages are heard in the environment (Northern Sámi and her brother's screaming) but not really used. Then there is a category of languages Oona would like to know as an adult (Norwegian, English, French). We need be bear in mind, of course, that the questionnaire gave the children these categories, but the children chose the languages or left some parts blank, and there was considerable variation among the children.

After the questionnaire, the drawing task and the related discussions (see Figure 2.1), the children started to work on their picture book. Working on the book took several lessons. The children could decide on the topic, but the teachers provided help when needed. It was agreed in class that each child would include his/her own Sámi language and the other Sámi language spoken in the area, so everyone would have at least Northern Sámi and Inari Sámi in their book. In addition, the children could choose any other languages they wished to have, and their text would be translated into these chosen languages. The children were also aware that the books would be officially printed, launched and circulated in the community (for details see Pitkänen-Huhta and Pietikäinen 2014).

Figure 2.4 shows a double-page opening in Oona's book, the topic of which was a girl who wanted to be in a jungle. In the finished product Oona did not include all the languages she had mentioned in the questionnaire, but in addition to Inari Sámi and Northern Sámi she chose to include Norwegian, Swedish, and English. 


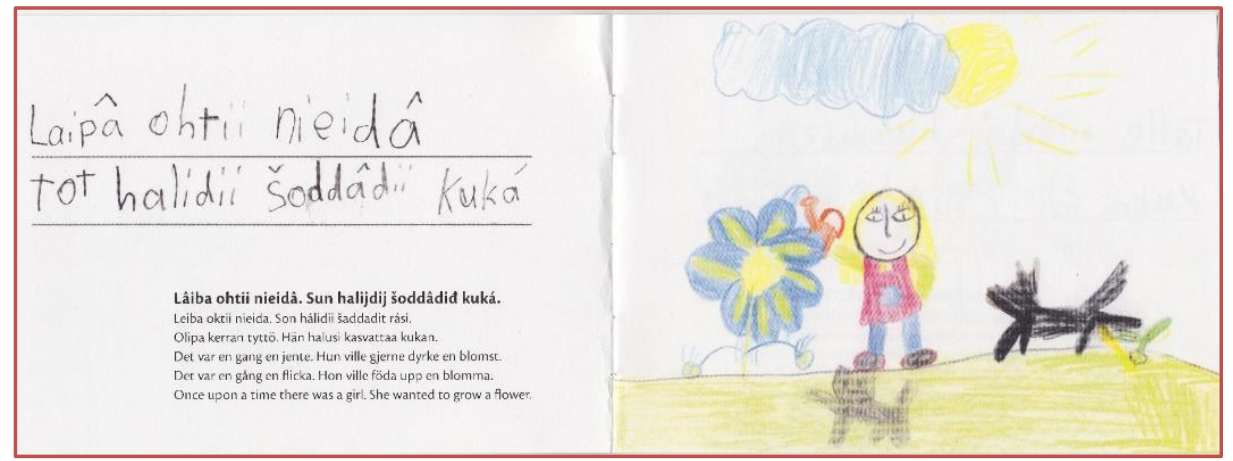

Fig. 2.4 Opening in Oona's book

This may reflect Oona's actual physical surroundings. Norwegian and Swedish are spoken in the neighbouring countries and the borders are easily crossed: relatives might well live in the parts of Sámiland stretching into Norway and Sweden. English, on the other hand, enters the children's environment via tourists, TV, music, and the internet. It seems that Oona, like the other children, was alert to the formality of the task and the audience of the book. Oona's fairly limited selection of languages in her book was typical of the choices in the books of the other children as well. This may indicate that the children mostly relied on a conventional and canonized literacy practice and resorted to named languages present in the immediate environment (see also Pietikäinen and Pitkänen-Huhta 2013).

To sum up the observations from the second data set, one could infer that the children in this particular multilingual context appeared to be well aware of the languages in their lives and had varied and creative language repertoires. However, it also became evident that when the context for literacy is formal and public, creative multilingualism is reduced and children easily resort to normative and conventionalized views of language and literacy.

\subsection{Discussion}

The aim of this chapter was to bring the concepts of language and literacy into dialogue in the context of multilingualism, and to look further into their relationship to learning through an examination of two different data sets. In the first data set, the understandings of language and language learning that emerge when young people talk about their literacy practices were examined. The second data set examined how children conceptualize their multilingual repertoires and how they make use of their resources in literacy practices. Both the data sets 
had literacy practices at their centre. In the first case, the focus was on everyday literacy practices, while in the second case the literacy practice was a formal and public one, carried out in the school context.

So what kinds of conceptualizations of literacy, language, and language use emerge from the data? The data discussed here shows that using language does not mean the use of a full language. It might only be a fragment of language, one may know hardly anything of it, or one may only recognize the language, but one might still be able to use it in one's literacy practices. Language use may also be passive, meaning one is just the recipient of language, or it may be a creative means of communication that would not be categorized as language in the conventional sense. Language use is also networked and contextual: different language resources are used with different people, in different contexts, and for different purposes. All this points towards the conceptualization of language as a resource. For these young people and children, language is not only a structure or a system in which they need to reach a particular threshold before they are able to use it; on the contrary, they happily engage in activities that involve languages of which they have very limited knowledge, or they include in their repertoire languages they do not know (in the conventional sense), or that are not languages at all in the conventional sense.

However, the concept of language seemed to be given different meanings in different contexts. When the focus was on everyday encounters with texts, literacy practice seemed to be primary and language secondary; language was embedded in social practice. Language was fluid and emerging, and also connected to wishes, future aspirations, and imagined communities. When the context for the literacy practice was a more formal one, embedded in a school task, it seemed that the literacy practice constrained creative and varied language use, and there was reliance on norm and convention, on a named and fixed conceptualization of language.

The issue of language learning and knowing a language also emerged from the data. Language learning appeared to be embedded in social practice and to be a by-product of social action, as in the examples of the young people checking song lyrics. Learning, to these young people, was not just making a conscious effort to develop as a language user; learning also seemed to be about being interested in and observant of the languages around one, recognizing languages and making use of whatever resources were available. Hopes and desires were connected to the future and to imagined communities, so there was potential 
investment in language learning. The concept of language learning is not only what I know and what I can do but it is also what I want to do and want to know.

The relationship between the concepts of language, literacy, and learning in multilingual contexts thus seems to be complex and changing. Language appears to be intertwined in literacy practice and language and literacy seem to be developing side by side. On the other hand, the concepts are changing and contextual. Literacy can be both liberating and constraining; language can be both fluid and fixed.

It is also evident that the participatory methods we used in the projects enabled us to bypass fixed and naturalized views of language, competence, proficiency and skills, and provide space for awareness raising and emancipation. It has to be kept in mind that one of the aims of the research projects was to raise the participants' awareness of their own literacy practices and language use as they were co-participating in the study. Further, the focus was on subjective experience. But when we are concerned with language, literacy, language use, literacy practices, and learning, it is the learners' and language users' understanding of these concepts that should be the starting point for the theorizing. As The Douglas Fir Group (2016, p. 29) points out, "when it comes to explaining what learning is, at least conceptually and often empirically, our various theories stipulate the mutual entailment of the cognitive, the social, and the emotional".

\section{References}

Anderson, Benedict. 1983. Imagined communities: Reflections on the origin and spread of Nationalism. London: Verso.

Auerbach, Elsa. 1995. The politics of ESL classroom: Issues of power in pedagogical choices. In Power and inequality in language education, ed. James W. Tollefson, 9-33. New York: Cambridge University Press.

Barton, David, and Mary Hamilton. 1998. Local literacies: Reading and writing in one community. London: Routledge.

Barton, David, Roz Ivanič, Yvon Appelby, Rachel Hodge, and Karin Tusting. 2007. Literacy, lives and Learning. Abingdon: Routledge.

Baynham, Mike, and Mastin, Prinsloo (eds). 2009. The future of literacy studies. Houndmills, Basingstoke: Palgrave Macmillan. 
Block, David. 2003. The social turn in second language acquisition. Edinburgh: Edinburgh University Press.

Blommaert, Jan. 2008. Grassroots literacy. Writing, identity, and voice in Central Africa. Abingdon: Routledge.

Blommaert, Jan. 2010. A sociolinguistics of globalization. Cambridge: Cambridge University Press.

Canagarajah, Suresh. 2007. After disinvention: Possibilities for communication, community and competence. In Disinventing and reconstituting languages, ed. Sinfree Makoni, and Alastair Pennycook, 233-239. Clevedon: Multilingual Matters.

Canagajarah, Suresh. 2013. Translingual practice. Global Englishes and cosmopolitan relations. Abingdon: Routledge.

Firth, Alan, and Johannes, Wagner. 1997. On Discourse, Communication, and (Some) Fundamental Concepts in SLA Research. The Modern Language Journal 81: 285-300.

Firth, Alan, and Johannes, Wagner. 2007. Second/foreign language learning as a social accomplishment: Elaborations on a reconceptualized SLA. The Modern Language Journal 91: 801-819.

Freire, Paulo, and Donaldo, Macedo. 1987. Literacy: Reading the word and the world. South Hadley, MA: Bergin \& Garvey.

Freire, Paolo. 1970. Pedagogy of the oppressed. New York: Continuum.

García, Ofelia. 2009. Bilingual education in the $21^{\text {st }}$ century. A global perspective. Chichester: Wiley-Blackwell.

Hornberger, Nancy. 1989. Continua of biliteracy. Review of Educational Research 59: 271296.

Hornberger, Nancy. 2003. Introduction. In Continua of biliteracy. An ecological framework for educational policy, research, and practice in multilingual settings, ed. Nancy Hornberger, xii-xxiii. Clevedon: Multilingual Matters.

Hornberger, Nancy. 2007. Biliteracy, transnationalism, multimodality, and identity: Trajectories across time and space. Linguistics and Education 18: 325-334.

Jaffe, Alexandra. 2003. Talk around text: Literacy practices, cultural identity and authority in a Corsican bilingual classroom. International Journal of Bilingual Education and Bilingualism 6: 202-220.

Kramsch, Claire. 2014. Teaching foreign languages in an era of globalization: Introduction. The Modern Language Journal 98: 296-311. 
Larsen-Freeman, Diane. 2013. Complexity Theory: A new way to think. RBLA, Belo Horizonte 13: 369-373.

Lau, Sunny Man Chu. 2012. Reconceptualizing critical literacy teaching in ESL classrooms. The Reading Teacher 65: 325-329.

Leppänen, Sirpa, Anne Pitkänen-Huhta, Tarja Nikula, Samu Kytölä, Timo Törmäkangas, Kari Nissinen, Leila Kääntä, Tiina Räisänen, Mikko Laitinen, Päivi Pahta, Heidi Koskela, Salla Lähdesmäki, and Henna Jousmäki. 2011. National Survey on the English Language in Finland: Uses, Meanings and Attitudes. Studies in Variation, Contacts and Change in English, vol 5. Helsinki: Research Unit for Variation, Contacts and Change in English.

Linell, Per. 2005. The Written Language Bias in Linguistics: Its Nature, Origins, and Transformations. London: Routledge.

Lo Bianco, Joseph. 2014. Domesticating the Foreign: Globalization's Effects on the Place/s of Languages. The Modern Language Journal 98: 312-325.

Makoni, Sinfree, and Alastair, Pennycook. 2007. Disinventing and reconstituting languages. In Disinventing and reconstituting languages, ed. Sinfree Makoni, and Alastair Pennycook, 1-41. Clevedon: Multilingual Matters.

May, Stephen. 2011. The disciplinary constraints of SLA and TESOL: Additive bilingualism and second language acquisition, teaching and learning. Linguistics and Education 22: $233-247$.

Nikula, Tarja. 2002. Teacher talk reflecting pragmatic awareness: A look at EFL and content-based classroom settings. Pragmatics 12: 447-467.

Nikula, Tarja and Pitkänen-Huhta, Anne. 2008. Using photographs to access stories of learning English. In Narratives of learning and teaching EFL, ed. Paula Kalaja, Vera Menezes, and Ana M. Ferreira Barcelos, 171-185. Basingstoke: Palgrave.

Norton, Bonnie. 2000. Identity and language learning. Gender, ethnicity and educational Change. Harlow: Pearson Education Limited.

Otsuji, Emi, and Alastair Pennycook. 2010. Metrolingualism: fixity, fluidity and language in flux. International Journal of Multilingualism 7: 240-254.

Pennycook, Alastair. 2010. Language as a local practice. London: Routledge.

Pennycook, Alastair, and Emi Otsuji. 2016. Lingoing, language labels and metrolingual practices. Applied Linguistics Review 7: 259-277. 
Pietikäinen, Sari, and Anne Pitkänen-Huhta. 2013. Multimodal literacy practices in the indigenous Sámi classroom: Children navigating in a complex multilingual setting. International Journal of Language, Identity and Education 12: 230-247.

Pietikäinen, Sari, and Anne Pitkänen-Huhta. 2014. Dynamic multimodal language practices in multilingual indigenous Sámi classrooms in Finland. In Minority Languages and Multilingual Education. Bridging the Local and the Global, ed. Durk Gorter, Victoria Zenotz, and Jasone Cenoz, 137-157. Heidelberg: Springer.

Pietikäinen, Sari. 2015. Multilingual dynamics in Sámiland: Rhizomatic discourses on changing Language. International Journal of Bilingualism 19: 206-225.

Pitkänen-Huhta, Anne. 2003. Texts and interaction: Literacy practices in the EFL classroom. Jyväskylä Studies in Languages 55. Jyväskylä: University of Jyväskylä.

Pitkänen-Huhta, Anne, and Tarja Nikula. 2013. Teenagers making sense of their foreign language practices: individual accounts indexing social discourses. In The applied linguistic individual: Sociocultural approaches to autonomy, agency and identity, ed. Phil Benson, and Lucy Cooker, 104-118. Sheffield: Equinox.

Pitkänen-Huhta, Anne, and Sari Pietikäinen. 2014. From a school task to community effort: children as authors of multilingual picture books in an endangered language context. In Children's Literature in Multilingual Classrooms, ed. Christine Helot, Ray Sneddon, and Nicole Daly, 138-153. London: Trentham Books.

Shor, Ira. 1999. What is critical literacy? Journal of Pedagogy, Pluralism, and Practice 1: Article 2. Available at: https://digitalcommons.lesley.edu/jppp/vol1/iss4/2

Street, Brian V. 1984. Literacy in theory and practice. Cambridge: Cambridge University Press.

The Douglas Fir group. 2016. A transdisciplinary framework for SLA in a multilingual world. The Modern Language Journal 100: 19-47. 